\title{
Antiviral Activities of High Energy E-Beam Induced Copper Nanoparticles against H1N1 Influenza Virus
}

\author{
Taesung Ha ${ }^{1,2,+}$, Thi Tuyet Mai Pham ${ }^{3,+}{ }^{+}$Mikyung Kim ${ }^{3}$, Yeon-Hee Kim ${ }^{2}$, Ji-Hyun Park ${ }^{2}$, Ji Hae Seo ${ }^{3}$, \\ Kyung-Min Kim ${ }^{1, *}$ and Eunyoung $\mathrm{Ha}^{3, *}$
}

1 Department of Nano Chemical Materials Engineering, Korea National University of Transportation, Chungju 27469, Korea; river@srsrad.com

2 Seoul Radiology Services Co., Seoul 02050, Korea; kimyhc@srsrad.com (Y.-H.K.); jhpark@srsrad.com (J.-H.P.)

3 Department of Biochemistry, School of Medicine, Keimyung University, Deagu 42601, Korea; phamtmai6@gmail.com (T.T.M.P.); balee96@naver.com (M.K.); seojh@dsmc.or.kr (J.H.S.)

* Correspondence: kmkim@ut.ac.kr (K.-M.K.); eyha@dsmc.or.kr (E.H.)

+ These authors contributed equally to the study.

check for updates

Citation: Ha, T.; Pham, T.T.M.; Kim, M.; Kim, Y.-H.; Park, J.-H.; Seo, J.H.; Kim, K.-M.; Ha, E. Antiviral Activities of High Energy E-Beam Induced Copper Nanoparticles against H1N1 Influenza Virus.

Nanomaterials 2022, 12, 268. https:// doi.org/10.3390/nano12020268

Academic Editors: Alberto Falco and Guogang Ren

Received: 9 December 2021

Accepted: 12 January 2022

Published: 14 January 2022

Publisher's Note: MDPI stays neutral with regard to jurisdictional claims in published maps and institutional affiliations.

Copyright: (C) 2022 by the authors. Licensee MDPI, Basel, Switzerland. This article is an open access article distributed under the terms and conditions of the Creative Commons Attribution (CC BY) license (https:// creativecommons.org/licenses/by/ $4.0 /)$.

\begin{abstract}
The pandemic outbreak of COVID-19 in the year of 2020 that drastically changed everyone's life has raised the urgent and intense need for the development of more efficacious antiviral material. This study was designed to develop copper nanoparticles (Cu NPs) as an antiviral agent and to validate the antiviral activities of developed copper NP. The $\mathrm{Cu}$ NPs were synthesized using a high energy electron beam, and the characteristic morphologies and antiviral activities of Cu NPs were evaluated. We found that $\mathrm{Cu}$ NPs are of spherical shape and uniformly distributed, with a diameter of around $100 \mathrm{~nm}$, as opposed to the irregular shape of commercially available copper microparticles ( $\mathrm{Cu}$ MPs). An X-ray diffraction analysis showed the presence of $\mathrm{Cu}$ and no copper oxide II and I in the $\mathrm{Cu}$ NPs. A virus inactivation assay revealed no visible viral DNA after 10- and 30-min treatment of H1N1 virus with the Cu NPs. The infectivity of the Cu NPs-treated H1N1 virus significantly decreased compared with that of the Cu MPs-treated H1N1 virus. The viability of A549 bronchial and Madin-Darby Canine Kidney (MDCK) cells infected with Cu NPs-treated H1N1 was significantly higher than those infected with $\mathrm{Cu}$ MPs-treated H1N1 virus. We also found cells infected with $\mathrm{Cu}$ NPs-treated H1N1 virus exhibited a markedly decreased presence of virus nucleoprotein (NuP), an influenza virus-specific structural protein, compared with cells infected with Cu MPs-treated H1N1 virus. Taken together, our study shows that $\mathrm{Cu}$ NPs are a more effective and efficacious antiviral agent compared with $\mathrm{Cu}$ MPs and offer promising opportunities for the prevention of devastatingly infectious diseases.
\end{abstract}

Keywords: copper; nanoparticle; influenza virus; antiviral activity; electron beam

\section{Introduction}

In the year 2020, the world experienced the pandemic outbreak of COVID-19, a contagious disease caused by severe acute respiratory syndrome-coronavirus 2 (SARS-CoV-2) [1]. Contrary to everyone's expectation that the outbreak would subside soon, COVID-19 continued to the year 2021. Extraordinary public health measures have been implemented worldwide to prevent the virus from spreading, ranging from transport restriction and quarantine to social distancing and isolation [2]. This unprecedented calamity has raised the urgent and intense need for the development of antiviral materials with the highest efficacy to keep highly contagious viruses at bay [3]. One such candidate is copper (Cu) because, compared to other antimicrobial and antiviral materials, such as silver and gold, copper is cheaper and more easily accessible, which makes it very favorable as a commodity for daily application [4].

$\mathrm{Cu}$ is an essential trace element. It transmits electricity and transfers heat with the highest conductivity amongst any metal [5]. $\mathrm{Cu}$ is an essential micronutrient. It catalyzes 
heme synthesis and iron absorption that sustains lives [6]. $\mathrm{Cu}$ is also an antimicrobial agent. Its usage as an antimicrobial agent by human civilization dates back between 2600 and 2200 B.C. [7,8]. The Egyptians used Cu to sterilize chest wounds and to purify drinking water [8]. The Romans, Greeks, and others followed and used $\mathrm{Cu}$ for the treatment of infections and for hygienic purposes [8].

The use of $\mathrm{Cu}$ in medicine continued, and, today, the antimicrobial activities of $\mathrm{Cu}$ are firmly established [7,9-11]. The Environmental Protection Agency officially announced $\mathrm{Cu}$ and its alloys as antimicrobial metallic agents in 2008 (http: / / archive.epa.gov/pesticides / registration/web/pdf/copper_red_fs.pdf, access on 2 November 2021). Cu and Cu alloys show a broad spectrum of antimicrobial activities against various bacteria, such as E. coli, S. aureus, P. aeruginosa, and K. aerogenes [12-14]. The antiviral activities of Cu, however, have not been well established. Moreover, the antiviral activities of $\mathrm{Cu}$ have not been elucidated as much as those of other antiviral agents, such as silver.

Like $\mathrm{Cu}$, silver has been used to prevent infections since antiquity [15]. The antiviral effect of silver was evaluated and confirmed in Newcastle disease virus-infected chicken eggs [16]. Moreover, the antiviral activities of silver against influenza virus A, herpes simplex viruses, and HIV-1 virus were extensively demonstrated [17-22]. Curcumin extract-derived silver showed highly efficient antiviral activity against respiratory syncytial virus [23]. In addition, studies showed silver-induced apoptosis reflected by caspase 3 activation, DNA fragmentation, and chromatin condensation $[17,24]$.

We previously showed enhanced conductivity of high energy electronic beam (Ebeam)-induced $\mathrm{Cu}$ nanoparticles ( $\mathrm{Cu}$ NPs) [25]. The synthesis of E-beam-induced $\mathrm{Cu}$ NPs, compared to commercially available $\mathrm{Cu}$ microparticles ( $\mathrm{Cu}$ MPs) synthesized by mechanical milling, requires fewer procedural steps and less time, which makes them suitable for mass production. The size of E-beam-induced $\mathrm{Cu}$ NPs can also be adjusted by varying the irradiation dose or dose rate. We reasoned, based on the enhanced conductivity of Ebeam-induced $\mathrm{Cu}$ NPs, that E-beam-induced $\mathrm{Cu}$ NPs would show effective and efficacious antiviral activities. Thus, with the urgent necessity to establish the antiviral role of $\mathrm{Cu}$, we designed and conducted the current study.

\section{Materials and Methods}

\subsection{Materials}

All aqueous solutions were prepared using deionized water (Milipore, Merck, Seoul, Korea, specific resistivity $\geq 18.2 \mathrm{M} \Omega \mathrm{cm}$ ) and ethylene glycol (EG, JUNSEI, Tokyo, Japan) with a ratio of 50:50. Cu sulphate pentahydrate $\left(\mathrm{CuSO}_{4}: 5 \mathrm{H}_{2} \mathrm{O}, 99 \%\right.$, Sigma Aldrich, Seoul, Korea) was used as a metal salt, and polyvinylpyrrolidone (PVP) (Mw = 360,000) was used as a dispersing agent. The isopropyl alcohol (IPA, 99\% DUKSAN, Seoul, Korea) was used as a radical scavenger to remove hydroxyl radical. $\mathrm{Cu}$ MPs that had been synthesized primarily by mechanical jet milling were purchased from $\mathrm{K} \mathrm{H}$ Tech, Incheon, Korea.

\subsection{Synthesis of $\mathrm{Cu} N \mathrm{NS}$}

Radiolytic method was used for the synthesis of $\mathrm{Cu}$ NPs using $10 \mathrm{MeV}$ of high energy E-beam. Deionized water and ethylene glycol (50:50 ratio) were mixed in a $100 \mathrm{~mL}$ beaker. $\mathrm{CuSO}_{4}: 5 \mathrm{H}_{2} \mathrm{O}(0.05 \mathrm{M})$ was dispersed in the solution, followed by the addition of $1.2 \mathrm{~g}$ of dispersing agent and $2 \mathrm{M}$ of isopropyl alcohol. After the mixture was stirred with the mechanical stirrer at $500 \mathrm{rpm}$ for $1 \mathrm{~h}$, oxygen in the solution was removed by $\mathrm{N}_{2}$ gas. The reaction mixture was transferred to a culture, then irradiated using E- beam $(10 \mathrm{MeV}$, $20 \mathrm{~kW}$ ). The absorbed dose was $80 \mathrm{kGy}$ and dose rate was $2 \mathrm{kGy} / \mathrm{s}$. The obtained $\mathrm{Cu}$ NPs suspension was centrifuged at $7000 \mathrm{rpm}$ for $20 \mathrm{~min}$ and the clear supernatant solution was discarded. The sediments were washed by formic acid several times then desiccated at $40{ }^{\circ} \mathrm{C}$ under vacuum desiccator. The overall process of the synthesis of $\mathrm{Cu}$ NPs is illustrated in Figure 1. 

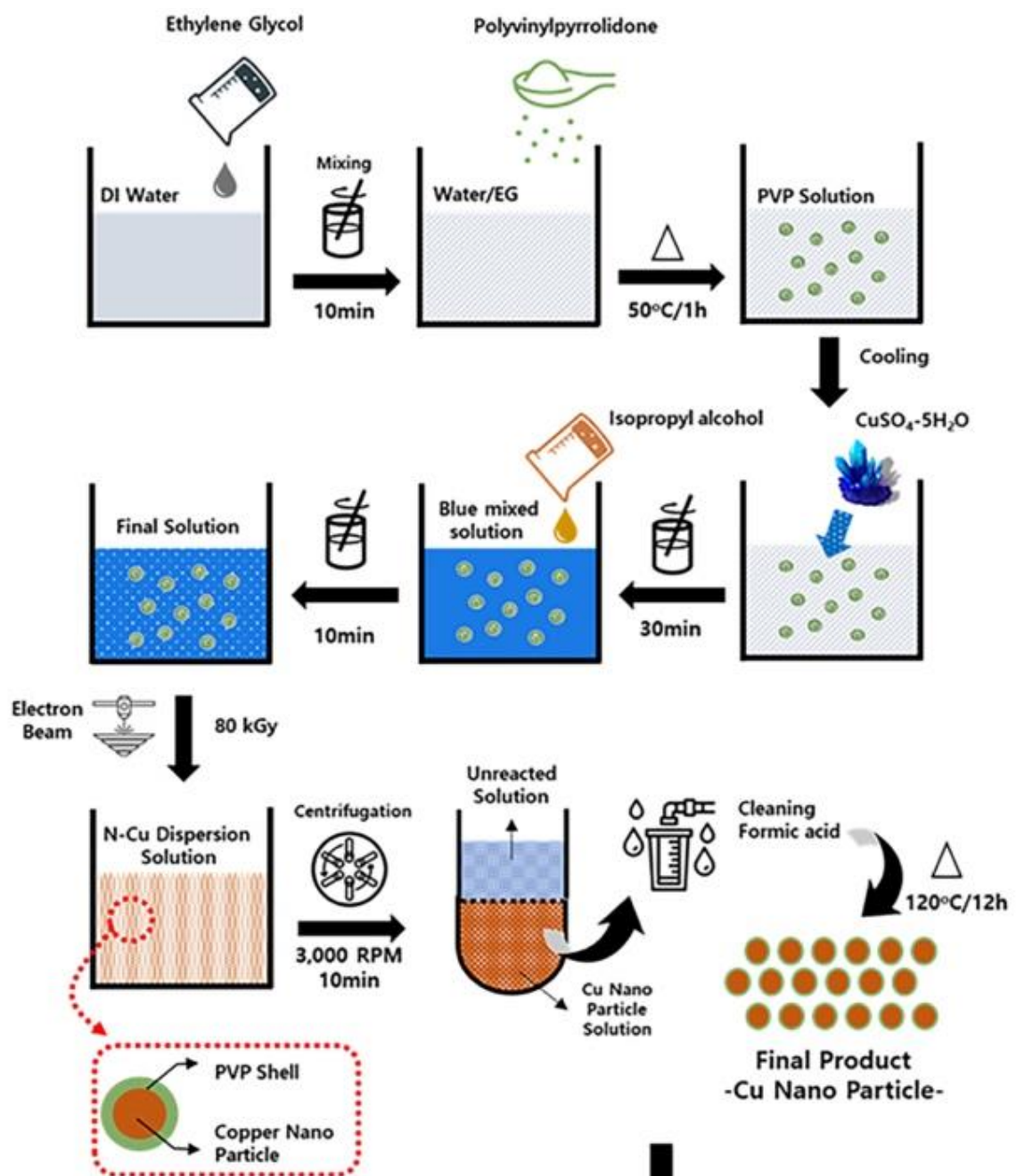

Repeat Purification (3 times)

Figure 1. Preparation procedures of copper nanoparticles (Cu NPs).

\subsection{Characterization of $\mathrm{Cu} N \mathrm{NS}$}

The phase analysis of the $\mathrm{Cu}$ NPs was conducted by X-ray powder diffraction (XRD, Smartlab, Rigaku Corporation, Tokyo, Japan) with $\mathrm{Cu} \mathrm{K} \alpha$ radiation $(\lambda=1.54178 \AA$ ). The morphologies of the particles were investigated using the field-emission scanning electron microscope (SEM, Sirion, FEI, Hillsboro, OR, USA) with accelerating voltage of $30 \mathrm{kV}$ equipped with an energy dispersive spectroscopy (EDS) and the field emission transmission electron microscopy (TEM, JEM-2100F HR, JEOL Ltd., Tokyo, Japan) with accelerating voltage of $200 \mathrm{kV}$.

\subsection{Cell Culture and Virus Propagation}

A549 adenocarcinomic human alveolar basal epithelial and Madin-Darby Canine Kidney (MDCK) cells were purchased from Korean Cell Line Bank and were maintained in monolayer in Roswell Park Memorial Institute Medium (RPMI) and Dulbecco's Modified Eagle Medium (DMEM), respectively, supplemented with $10 \%$ fetal bovine serum (FBS) at $37^{\circ} \mathrm{C}$ and $5 \% \mathrm{CO}_{2}$.

Influenza A (H1N1) virus was purchased from Korean Bank for Pathogenic Viruses. Viruses were propagated in MDCK cells. One day before inoculation, MDCK cells were seeded in T75 flask. When the cells were at $80-90 \%$ confluence, cells were infected with 
virus and incubated for $2 \mathrm{~h}$ at $37^{\circ} \mathrm{C}$. After infection, cells were washed with PBS, followed by addition of virus growth media containing MEM, BSA 7.5\% (Sigma-Aldrich, St. Louis, MO, USA), TPCL-trypsin $2 \mu \mathrm{g} / \mathrm{mL}$ (Sigma-Aldrich, St. Louis, MO, USA). When 80-90\% of cells detached from the flask, culture medium was collected and centrifuged at $1500 \mathrm{rpm}$ for 5 min. Supernatant containing viruses was collected and stored at $-80{ }^{\circ} \mathrm{C}$.

\subsection{Fifty Percent Tissue Culture Infectious Dose $\left(T_{C I D}\right)$ Assay}

$\mathrm{TCID}_{50}$ was used to measure the titration and infectivity of viruses. Briefly, cells were seeded into 96-well plates and incubated for $24 \mathrm{~h}$. Viruses were incubated with the absence or presence of $\mathrm{Cu}$ MPs and $\mathrm{Cu}$ NPs for $10 \mathrm{~min}$, and $100 \mu \mathrm{L}$ of incubated samples was used to infect cells as described in Section 2.6. After infection, cells were incubated for additional $48 \mathrm{~h}$. After $48 \mathrm{~h}$, cells were washed with phosphate buffered solution (PBS), fixed with $4 \%$ paraformaldehyde-PBS (Fujifilm, Osaka, Japan) for $20 \mathrm{~min}$, and stained with crystal violet solution for $10 \mathrm{~min}$ at room temperature (RT). The TCID 50 per $\mathrm{mL}$ was calculated according to Reed and Muench method [26].

\subsection{Virus Infection}

MDCK or A549 adenocarcinomic human alveolar basal epithelial cells were seeded into 6-well culture plates for $20-24 \mathrm{~h}$ at $37{ }^{\circ} \mathrm{C}$ and $5 \% \mathrm{CO}_{2}$ before infection. When the confluence of cells reached $80-90 \%, 200 \mu \mathrm{L}$ of $\mathrm{H} 1 \mathrm{~N} 1\left(\mathrm{TCID}_{50} / \mathrm{mL}=1.2 \times 10^{10}\right)$ in PBS containing $0.1 \mathrm{mM} \mathrm{CaCl}_{2}, 0.1 \mathrm{mM} \mathrm{MgCl}_{2}, 100 \mathrm{U} / \mathrm{mL}$ penicillin $0.1 \mathrm{mg} / \mathrm{mL}$ streptomycin, 7.5\% BSA (Sigma-Aldrich, St. Louis, MO, USA), TPCL-trypsin $2 \mu \mathrm{g} / \mathrm{mL}$ (Sigma-Aldrich, St. Louis, MO, USA) were added into the cells and incubated for $1 \mathrm{~h}$. After infection, viral solutions were removed, cells were washed briefly by PBS, and cell culture media were added into cells.

\subsection{Virus Inactivation Assay}

$\mathrm{Cu}$ MPs and $\mathrm{Cu}$ NPs were dispersed in PBS $(5 \% w / v)$. To evaluate the antiviral activities, $\mathrm{Cu}$ MPs and $\mathrm{Cu}$ NPs solutions were added to virus solution $\left(\mathrm{TCID}_{50} / \mathrm{mL}=1.2 \times 10^{10}\right.$ ) to the final concentration of $0.5 \% w / v$ and incubated for 0,10 , and $30 \mathrm{~min}$. After incubation of $\mathrm{Cu}$ MPs or $\mathrm{Cu}$ NPs with virus for the indicated time, viral RNA was isolated using RibospinTM vRD (GeneAll, Seoul, Korea) as recommended by the manufacturer.

\subsection{Cellular RNA Isolation and Polymerase Chain Reaction (PCR) Analysis}

Total RNA in cells was isolated using TRIzol Reagent (Life Technology, Carlsbad, CA, USA), as recommended by the manufacturer. RNA purity and concentration were determined by ASP2680 spectrophotometer (ATCGene, Madison, CT, USA). PCR analysis was conducted using 5X Green Gotaq Flexi Buffer (Promega, Madison, WI, USA) and 1.2\% of agarose gel electrophoresis was used to separate DNA fragments. Primers for H1N1 influenza virus-specific hemagglutinin (HA) protein were used to determine H1N1 virus. Expression levels of cellular H1N1 virus HA protein were normalized against $\beta$-actin, an internal control of A549 and MDCK cells. Primers for $\beta$-actin, human and canine, and HA protein are as follows:

HA protein (H1N1 virus) Forward 5'-CCCAGGRTATTTCKCCGAYTATGAGG-3'

Reverse 5'-TACCATTCCAGTCCACCCCCTTCA-3'

$\beta$-actin (human) Forward 5'-GGACTTCGAGCAAGAGATGG-3'

Reverse 5'-AGCACTGTGTTGGCGTACAG-3'

$\beta$-actin (canine) Forward 5'-GCGCAAGTACTCTGTGTGGA-3'

Reverse $5^{\prime}$-AAAGCCATGCCAATCTCATC-3'

\subsection{Cell Viability Assay}

Cells $\left(2 \times 10^{4}\right.$ cells $\left./ \mathrm{mL}\right)$ were seeded into 96-well plates and were incubated at $37{ }^{\circ} \mathrm{C}$ and $5 \% \mathrm{CO}_{2}$ for $24 \mathrm{~h}$. Viruses were incubated with $\mathrm{Cu}$ MPs or $\mathrm{Cu}$ NPs suspensions as described in Section 2.7 for indicated times and then added to cells for infection. Twenty- 
four hours after infection, $10 \mu \mathrm{L}$ Cell Counting Kit-8 (Dojindo, Rockville, MD, USA) reagent was added to each well and the cells were incubated for $1 \mathrm{~h}$ at $37^{\circ} \mathrm{C}$. The optical density was measured at $450 \mathrm{~nm}$ by a microplate spectrophotometer. Morphological characterization was analyzed using inverted microscope Olympus CKX53 (Olympus, Tokyo, Japan) with different magnifications and digitally visualized using software iSolution Auto plus (IMT Inc., Daejeon, Korea). For the evaluation of Cu MPs and Cu NPs cytotoxicity, Cu MPs and $\mathrm{Cu}$ NPs were first dispersed in PBS $(5 \% w / v)$, added to cells to the final concentration of $0.5 \% w / v$, and incubated for the indicated time.

\subsection{Western Blot and Coomassie Blue Staining}

$\mathrm{Cu}$ MPs and $\mathrm{Cu}$ NPs solutions were added to virus solution to the final concentration of $0.5 \% w / v$ and incubated for 0,10 , and $30 \mathrm{~min}$. After the incubation, samples were ultracentrifuged at $100,000 \times g$ for $2 \mathrm{~h}$ at $4{ }^{\circ} \mathrm{C}$. Obtained samples were lysed in RIPA buffer (Thermo Fisher Scientific, Rockford, IL, USA). Five micrograms of protein from each sample were resolved by sodium dodecyl sulphate-polyacrylamide gel electrophoresis (SDS-PAGE) gels and then stained with Coomassie blue or analyzed by immunoblotting. Anti-nucleoprotein $(\mathrm{NuP})$ (Abcam, Cambridge, UK) was used to detect the presence of virus.

\subsection{Confocal Microscopy}

Confocal microscopy was used to observe the localization of influenza H1N1 virus and to visually determine the antiviral effects of $\mathrm{Cu}$ MPs and $\mathrm{Cu}$ NPs in MDCK or A549 cells. After being incubated with $\mathrm{Cu}$ MPs or $\mathrm{Cu}$ NPs for the indicated times, viruses were used to infect cells for $1 \mathrm{~h}$. Then, cells were washed with PBS and fixed in paraformaldehyde PBS (Fujifilm, Osaka, Japan) for 20 min at RT. Cells were then permeabilized with 0.1\% Triton X-100 in PBS for 10 min and blocked with $1 \%$ bovine serum albumin (BSA) in PBS-T for $30 \mathrm{~min}$ at RT. After blocking, cells were incubated with mouse monoclonal antibody against viral NuP (1:200) (Abcam, Cambridge, UK) overnight at $4{ }^{\circ} \mathrm{C}$ and goat antibody mouse (1:1000) (Thermo Fisher Scientific, Rockford, IL, USA) for $1 \mathrm{~h}$ at RT. Nuclei were stained using 4',6-diamidino-2-phenylindole (DAPI). Fluorescence was visualized with a Carl Zeiss LSM5 EXCITER fluorescence microscope (Carl Zeiss, Oberkochen, Germany).

\section{Results and Discussions}

\subsection{Morphological Analysis of $\mathrm{Cu} N \mathrm{NS}_{\mathrm{s}}$ and $\mathrm{Cu} \mathrm{MPs}$}

Previous studies suggested that the dose for the synthesis of $\mathrm{Cu}$ NPs with a uniform and nano-dimensional shape requires over $300 \mathrm{kGy}[25,27,28]$. However, we found in the current study that $80 \mathrm{kGy}$ is required when a high energy E-beam $(10 \mathrm{MeV})$ is used to produce a high-yield and consistent, as well as reproducible, synthesis of $\mathrm{Cu}$ NPs. Over various methods for the synthesis of $\mathrm{Cu}$ NPs, including vacuum vapor deposition, microemulsion, mechanical milling, electrolysis, and aqueous solution reduction [29-33], the E-beam-induced synthesis of Cu NPs is advantageous in that the shape and size can be controlled, as reflected in Figure 2A.

We employed SEM to confirm and validate the size and morphology of Cu NPs synthesized by $10 \mathrm{MeV}$ high energy E-beam. The upper panels of Figure 2A show SEM images of $\mathrm{Cu}$ NPs synthesized by high energy E-beam. The shape of the particles is spherical, and the sizes of the particles are even with the diameter of about $100 \mathrm{~nm}$ as compared to the larger sizes in the dimension of $\mu \mathrm{m}$ and the irregular shape of Cu MPs (Figure 2B). The size and shape of $\mathrm{Cu}$ MPs are in line with a previous study [34].

We also performed further morphological analysis using TEM. The lower panels of Figure 2A show that the size and shape of $\mathrm{Cu}$ NPs are consistent with those of SEM analysis. The magnified TEM image with the scale of $10 \mathrm{~nm}$ revealed that the $\mathrm{Cu}$ NPs with the size of $100 \mathrm{~nm}$ are agglomerated with smaller nanoparticles of 10 to $20 \mathrm{~nm}$ in size.

As shown in Figure 2, most $\mathrm{Cu}$ NPs and $\mathrm{Cu}$ MPs are spherical. Thus, the surface-tovolume ratio of the $\mathrm{Cu}$ NPs and $\mathrm{Cu}$ MPs is 3/r, where $r$ is the radius [35]. As r decreases, the surface-to-volume ratio increases. Assuming the radius of $\mathrm{Cu}$ MPs is $3.0 \mu \mathrm{m}$ and that 
of agglomerated $\mathrm{Cu}$ NPs is $100 \mathrm{~nm}$, the reactive surface of $\mathrm{Cu}$ NPs is 30 times higher than that of $\mathrm{Cu}$ MPs for the same volume. Thus, with the radius of individual $\mathrm{Cu}$ NPs being approximately $10-20 \mathrm{~nm}$, the surface-to-volume ratio of $\mathrm{Cu}$ NPs would increase up to 150 to 300 times that of $\mathrm{Cu}$ MPs.

\section{A}
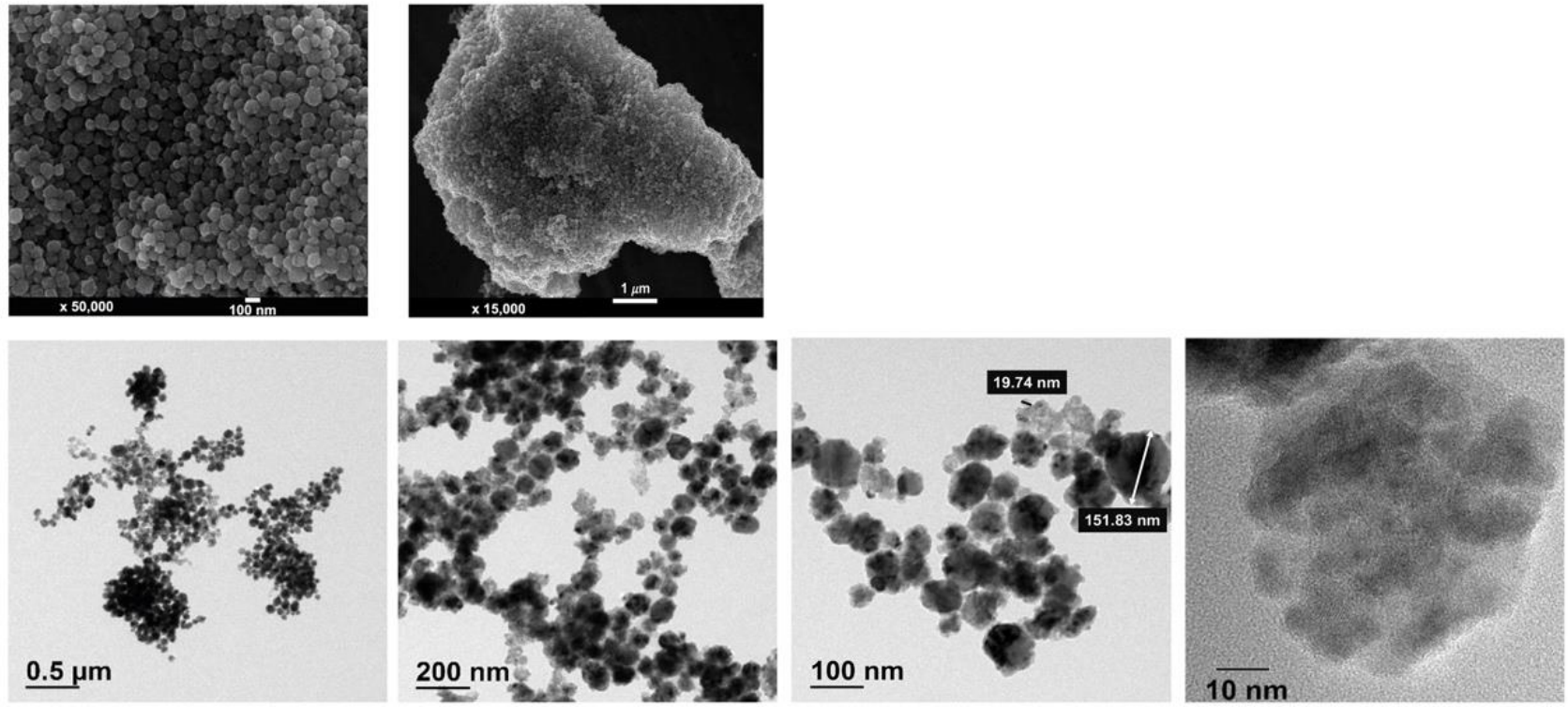

B
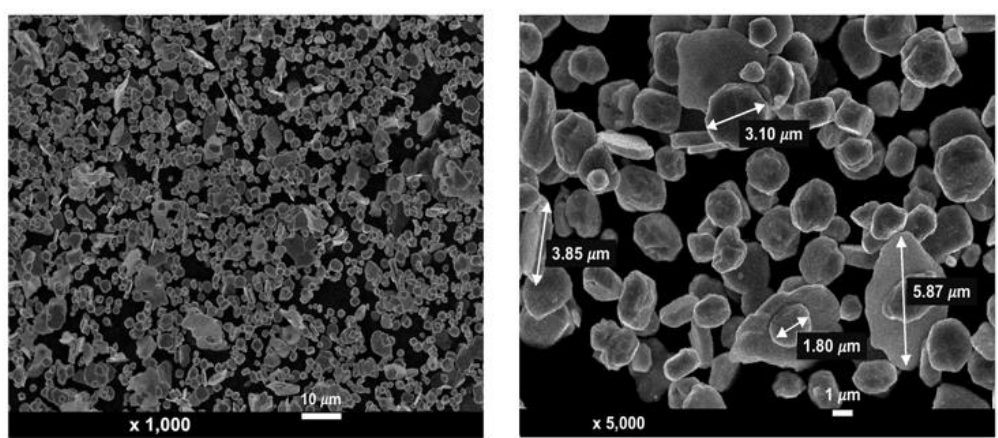

Figure 2. Scanning electron microscopy (SEM) and transmission electron microscopy (TEM) images of copper $(\mathrm{Cu})$ nanoparticles ( $\mathrm{Cu}$ NPs) synthesized by high energy E-Beam irradiation (A) and SEM images of $\mathrm{Cu}$ microparticles (Cu MPs) (B).

\subsection{Characteristic Analysis of $\mathrm{Cu} N \mathrm{~N}$}

Due to their superb electrical conductivity, low cost, and excellent biocompatibility, $\mathrm{Cu}$ and $\mathrm{Cu}$-based compounds have been gaining much attention in the areas ranging from future nanodevices to control of infectious diseases in healthcare [36,37]. Despite the above-mentioned advantages, however, the synthesis of $\mathrm{Cu}$ NPs is very challenging since $\mathrm{Cu}$ NPs are easily oxidized when exposed to the air and unstable in solution. The additional advantage of the E-beam-induced synthesis of $\mathrm{Cu}$ NPs is that irradiation can generate appropriate reducing radicals without the production of any byproducts [28].

$\mathrm{XRD}$ is a powerful technique to identify the crystalline phase present in the materials and to determine the structural properties, such as strain state, grain size, phase compo- 
sition, preferred orientation, and structural defect, of the phase. $\mathrm{Cu}$ is highly susceptible to oxidation and easily converted into $\mathrm{Cu}$ impurities, such as $\mathrm{Cu}$ oxide $\mathrm{II}(\mathrm{CuO})$ and $\mathrm{Cu}$ oxide $\mathrm{I}\left(\mathrm{Cu}_{2} \mathrm{O}\right)$. Thus, we investigated if $\mathrm{Cu}$ NPs and $\mathrm{Cu}$ MPs contain $\mathrm{CuO}$ or $\mathrm{Cu}_{2} \mathrm{O}$ by XRD analysis. The diffraction angles $(2 \theta)$ of the XRD analysis of $\mathrm{Cu}$ NPs and Cu MPs in Figure 3A correspond to those of pure $\mathrm{Cu}$ in Figure $3 \mathrm{~B}$ (peak values $2 \theta=43.3,50.3$, 74.2 degrees in Figure 3A), respectively, indicating $\mathrm{Cu}$ NPs and $\mathrm{Cu}$ MPs contain no $\mathrm{Cu}$ oxide impurities $\left(\mathrm{CuO}\right.$ or $\left.\mathrm{Cu}_{2} \mathrm{O}\right)$. Further investigation of $\mathrm{Cu}$ NPs and $\mathrm{Cu}$ MPs by EDS analysis, an analytical technique used for the elemental analysis, also reveals the main components of $\mathrm{Cu}$ NPs and $\mathrm{Cu}$ MPs are $\mathrm{Cu}(\sim 82 \%, \mathrm{Cu})$, suggesting that $\mathrm{Cu}$ ions in $\mathrm{Cu}$ NPs and $\mathrm{Cu}$ MPs are in the state of reduced form, not in the state of oxide form (Figure 4).

A
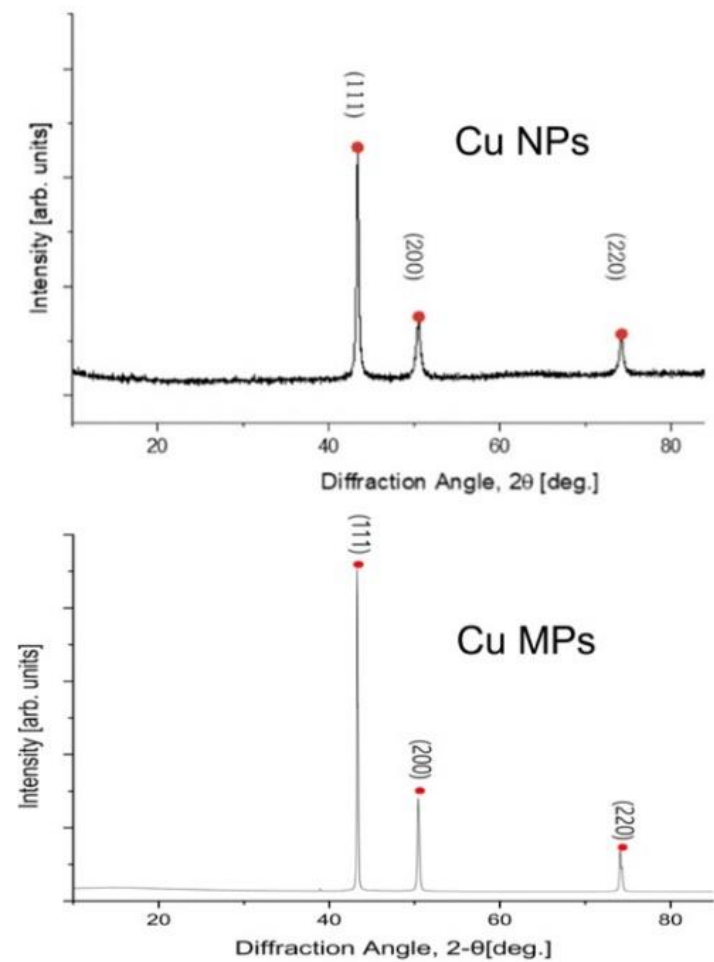

B

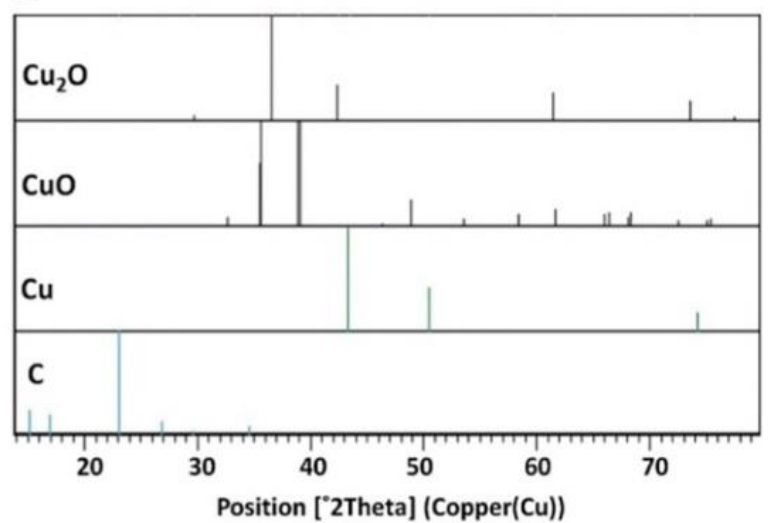

Figure 3. X-ray powder diffraction (XRD) pattern of copper $(\mathrm{Cu})$ nanoparticles $(\mathrm{Cu} N P s)$ and microparticles (Cu MPs) (A) and standard card of Joint Committee on Powder Diffraction Standards (JCPDS) (B). Pure Cu file No. 04-0836, $\mathrm{CuO}_{2}$ file No. 05-0667, CuO file No. 48-1548.

\subsection{Virus Inactivation by $\mathrm{Cu} N \mathrm{NS}$}

The antiviral activities of $\mathrm{Cu}$ have not been well exploited. Research regarding the antiviral role of $\mathrm{Cu}$ is still in its early stage and under intensive investigation. Recent studies showed the antiviral effects of $\mathrm{Cu}$ oxide against hepatitis $\mathrm{C}$ and herpes simplex viruses [38,39]. Other studies reported antiviral activities of $\mathrm{Cu}$ compounds against influenza viruses [40-42]. One possible antiviral mechanism of $\mathrm{Cu}$ is to inhibit viruses to enter and bind to host cells via interacting with the membrane glycoproteins of host cells. Another potential antiviral mechanism of $\mathrm{Cu}$ is to inactivate and degrade viral particles primarily via the generation of reactive oxygen species (ROS), leading to the degradation of the viral genome and proteins $[43,44]$. 
E

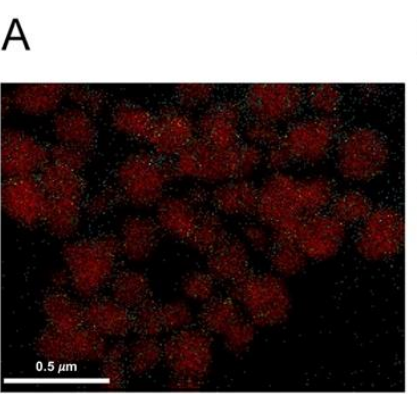

B
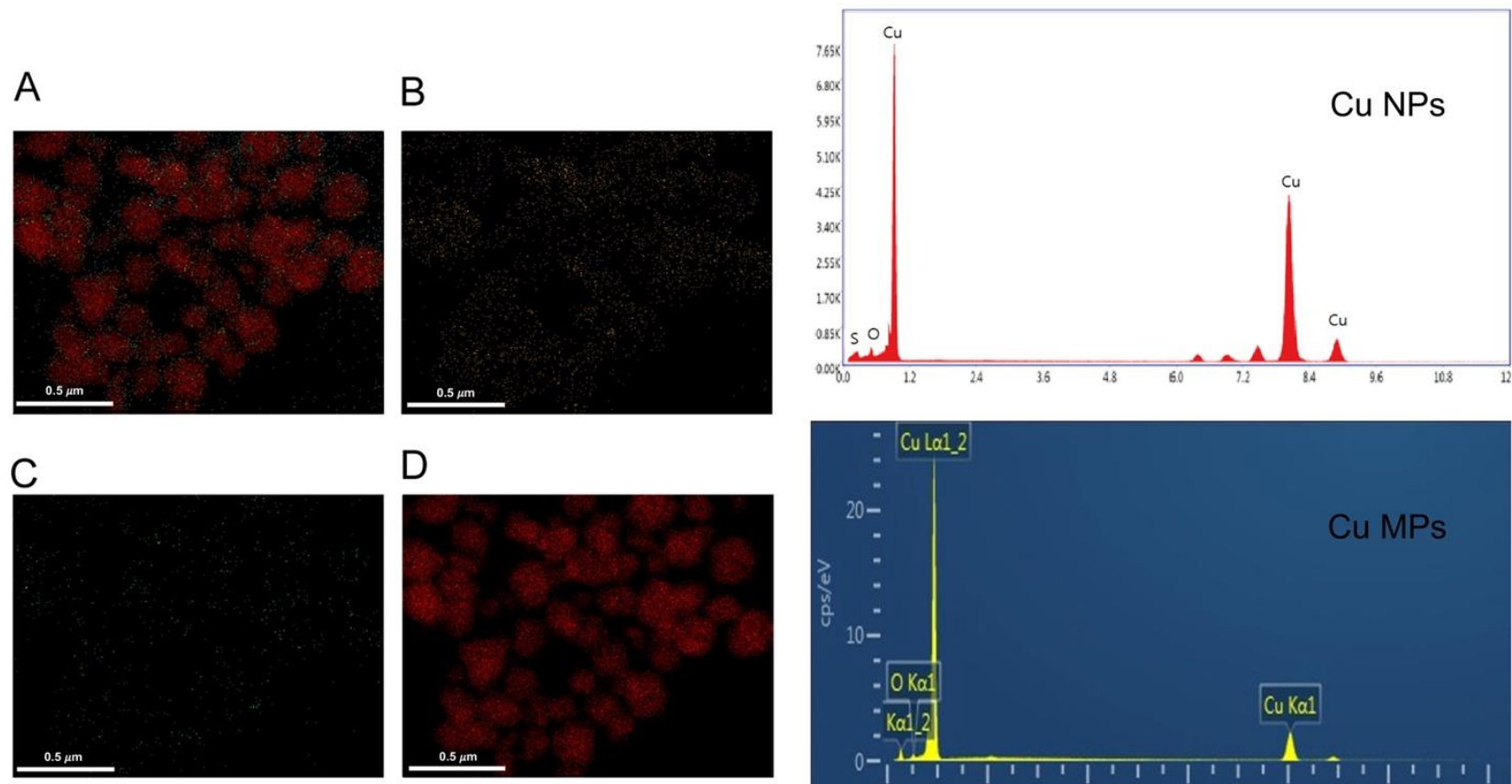

D
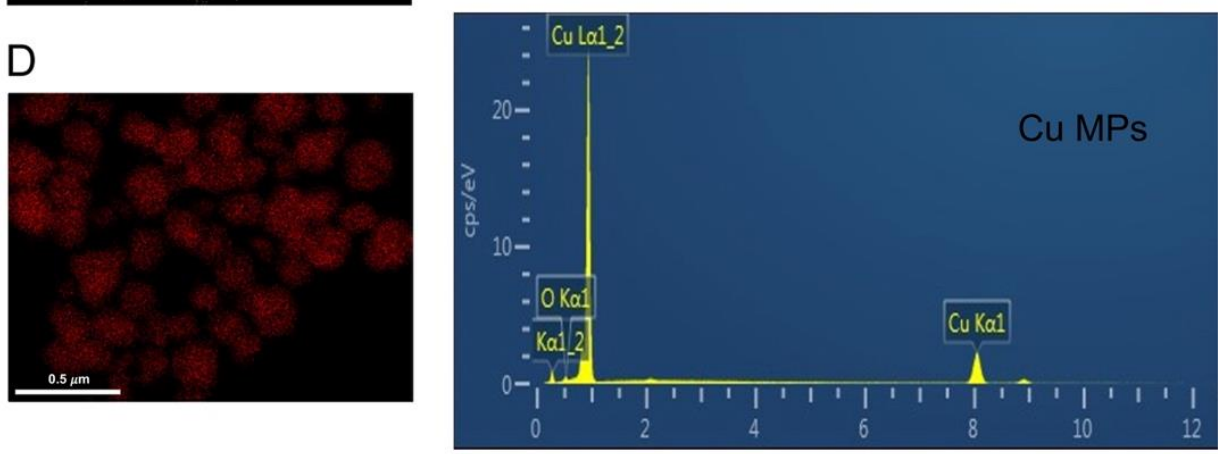

Figure 4. Energy dispersive spectroscopy (EDS) elemental spectrum and quantification results of copper (Cu) nanoparticles (Cu NPs). The EDS mapping of Cu NPs shows overlay (A), oxygen (B), sulfur $(C)$, and $\mathrm{Cu}(\mathrm{D})$ distributions in micrographs, respectively. The EDS spectrum reveals the main components (oxygen, sulfur, and $\mathrm{Cu}$ ) of $\mathrm{Cu}$ NPs and $\mathrm{Cu}$ microparticles (Cu MPs) (E).

Herein, with $\mathrm{Cu}$ NPs that we developed as more efficient and efficacious antiviral material, we then determined the efficacy of the antiviral activities of $\mathrm{Cu}$ NPs and possible antiviral mechanism of $\mathrm{Cu}$ NPs. We used commercially available $\mathrm{Cu}$ MPs as a positive control. Figure 5A exhibits the viral inactivation activities of $\mathrm{Cu}$ MPs and $\mathrm{Cu}$ NPs and degradation of the viral genome, HA gene. The expressions of the viral HA gene in the control, $0 \mathrm{~min}$, as expected, decreased in proportion to the incubation time since the viability of the virus is proportional to the time of exposure to open-air environment. However, the $\mathrm{Cu}$ MPs treatment into the H1N1 suspension decreased the expressions of the viral HA gene more profoundly at $30 \mathrm{~min}$ than the control, suggesting that the virus is inactivated and viral particles degraded by $\mathrm{Cu}$ MPs. To our expectation that the larger surface area of $\mathrm{Cu}$ NPs would exert stronger anti-viral activity, the expressions of the viral HA gene in $\mathrm{Cu}$ NPs at 10 and $30 \mathrm{~min}$ were not visible, implicating that the virus is strongly inactivated by $\mathrm{Cu}$ NPs. The expressions of the viral HA gene in the $\mathrm{Cu}$ NPs-treated virus markedly decreased at 10 and 30 min compared with those in the $\mathrm{Cu}$ MPs-treated virus. These data clearly demonstrate that the antiviral activity of Cu NPs against H1N1 influenza virus is superior to that of $\mathrm{Cu}$ MPs.

To validate further that the virus is indeed inactivated and degraded, we then determined the viral proteins by western blot analysis (Figure 5B). The upper panel of Figure 5B represents Coomassie blue-stained viral proteins, $\mathrm{HA}, \mathrm{NuP}$, and neuraminidase [45]. The lower panel of Figure 5B represents the western blot analysis of NuP. Almost no protein bands are visible at $30 \mathrm{~min}$ of $\mathrm{Cu}$ NPs in both the Coomassie blue and western blot analyses, indicating the degradation of viral particles. 
A

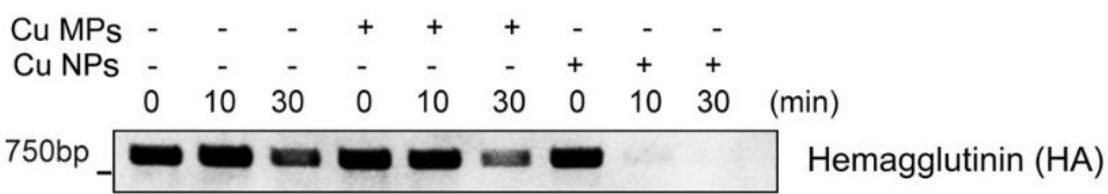

B
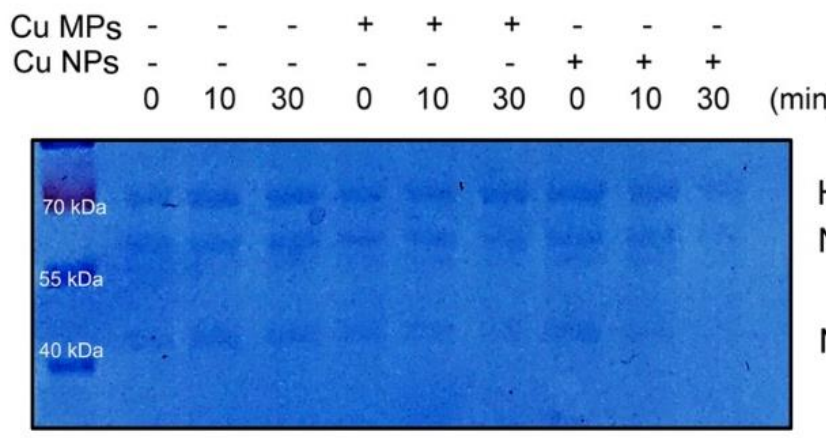

$\mathrm{HA}$

Nucleoprotein (NuP)

Neuraminidase

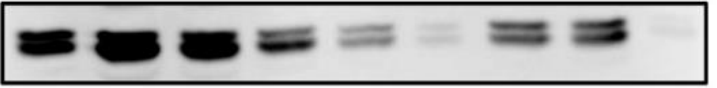

NuP

Figure 5. The antiviral effects of copper (Cu) microparticles (Cu MPs) and $\mathrm{Cu}$ nanoparticles (Cu NPs) against $\mathrm{H} 1 \mathrm{~N} 1$ virus. (A) Viral inactivation assay. H1N1 virus was incubated with the absence or presence of $\mathrm{Cu}$ MPs or $\mathrm{Cu}$ NPs between $10 \mathrm{~min}$ and $30 \mathrm{~min}$ and analyzed for virus-specific heme agglutinin (HA) gene by PCR analysis. (B) Coomassie bule staining (upper panel) of viral proteins and western blot analysis (lower panel) of viral nucleoprotein (NuP) from viral inactivation assay $(1,10$, and $30 \mathrm{~min})$.

\subsection{Infectivity of Cu NPs-Treated Virus}

To further evaluate the anti-viral activity of $\mathrm{Cu}$ NPs compared to that of $\mathrm{Cu}$ MPs, we next determined the presence of cellular viral particles by confocal microscopy. MDCK cells were infected with H1N1 virus, $\mathrm{Cu}$ MPs-treated virus, and $\mathrm{Cu}$ NPs-treated virus (Figure 6A). We used virus-specific NuP antibody to detect the presence of influenza virus. $\mathrm{NuP}$ is a highly conserved virus-specific protein that is most abundantly present in infected cells [46]. In the uppermost panels of Figure 6A, NuP protein is not visible in control cells that are not infected with virus, as expected. In the second upper panels of Figure 6A, $0 \mathrm{~min}$, cells infected with virus only showed a strong presence of NuP, and the treatment of the virus with $\mathrm{Cu}$ MPs and $\mathrm{Cu}$ NPs attenuated the presence of $\mathrm{NuP}$ around the cellular nucleus. Moreover, we observed less intensity of the fluorescence of NuP in cells infected with $\mathrm{Cu}$ NPs-treated virus than those infected with $\mathrm{Cu}$ MPs-treated virus. Of note, the intensities of fluorescence of $\mathrm{NuP}$ at 30 min of cells infected with $\mathrm{Cu}$ NPs-treated virus are similar to those of cells without virus infection, evidence that suggests a very effective antiviral activity of $\mathrm{Cu}$ NPs.

We then also evaluated the expressions of viral genome HA gene (Figure 6B) and observed consistent results with those of Figure 6A. The expressions of viral DNA in both A549 and MDCK cells infected with Cu NP-treated virus markedly decreased at 10 and 30 min compared with those infected with $\mathrm{Cu}$ MP treated virus. 
A

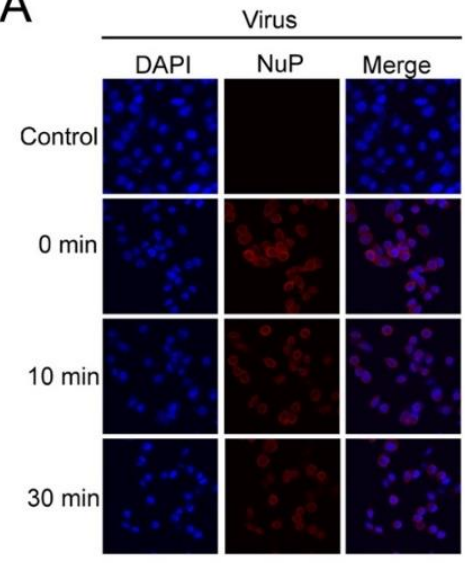

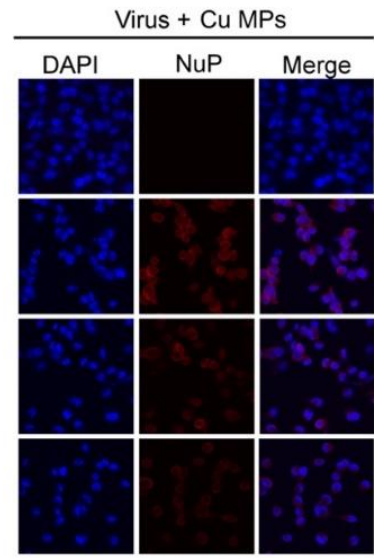

B

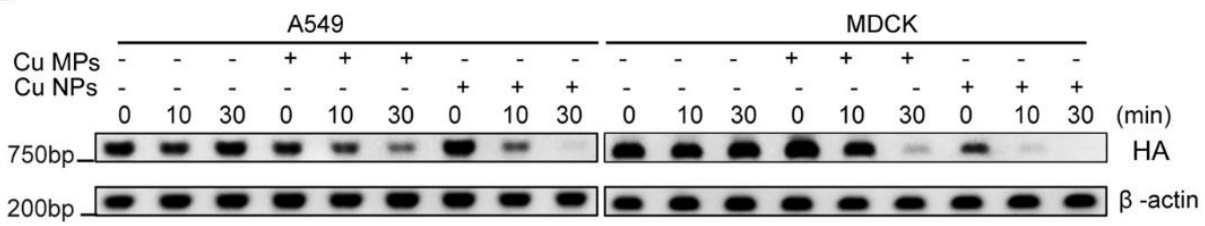

Figure 6. Copper $(\mathrm{Cu})$ microparticles ( $\mathrm{Cu}$ MPs) and $\mathrm{Cu}$ nanoparticles ( $\mathrm{Cu}$ NPs) induce decrease in $\mathrm{NuP}$ protein expression in infected cells. (A) Immunofluorescence confocal microscopy assay for $\mathrm{NuP}$ protein expression (red) in virus infected MDCK or A549 cells with the absence or presence of $\mathrm{Cu}$ MPs or $\mathrm{Cu}$ NPs at $24 \mathrm{~h}$ post infection. The cell nuclei were stained with DAPI (blue). (B) Standard PCR assay for viral hemagglutinin (HA) gene. A549 and MDCK cells were treated with samples from viral inactivation assay $(1,10$, and $30 \mathrm{~min})$ and incubated for $24 \mathrm{~h}$. Cellular RNA were extracted and analyzed by PCR assay for virus-specific HA gene.

Next, we determined the viabilities of A549 and MDCK cells infected with H1N1 virus, $\mathrm{Cu}$ MPs-treated virus, and $\mathrm{Cu}$ NPs-treated virus (Figure 7A). In line with the results from the viral inactivation assay, we found that the cell viabilities are significantly higher in both A549 and MDCK cells infected with Cu MPs- and Cu NPs-treated virus compared with those infected with virus alone. We also found that the cell viabilities are markedly higher in both A549 and MDCK cells infected with Cu NPs-treated virus compared with those infected with $\mathrm{Cu}$ MPs treated virus, another piece of evidence that the antiviral activity of $\mathrm{Cu}$ NPs is greater than that of Cu MPs. The lower panels of Figure 7A show cell morphologies consistent with the results from the upper panels of Figure 7A, cell viability assay. The $\mathrm{TCID}_{50}$ assay is an assay that is commonly used to quantify the number of infectious virus particles, the titration of the virus. We then determined the $\mathrm{TCID}_{50}$ values of the $\mathrm{H} 1 \mathrm{~N} 1$ virus alone, $\mathrm{Cu}$ MPs-treated $\mathrm{H} 1 \mathrm{~N} 1$ virus, and $\mathrm{Cu}$ NPs-treated H1N1 virus (Figure 7B) and found that the TCID 50 value of Cu NPs-treated H1N1 virus is significantly lower than those of the virus alone and $\mathrm{Cu}$ MPs-treated H1N1 virus, indicating lower viral infectivity when treated with $\mathrm{Cu}$ NPs. Finally, we investigated the cytotoxicity of $\mathrm{Cu}$ MPs and $\mathrm{Cu}$ NPs (Figure 7C). Additionally, we found no significant differences in cytotoxicity among the control, $\mathrm{Cu}$ MPs-treated, and $\mathrm{Cu}$ NPs-treated samples. These results are expected given the size difference between the virus and eukaryotic cells. The typical size of H1N1 influenza virus is 80 to $120 \mathrm{~nm}$ in diameter [47] and that of eukaryotic cells in the dimension of $\mu \mathrm{m}$, resulting in more than a million-fold difference in volume [48]. 
A
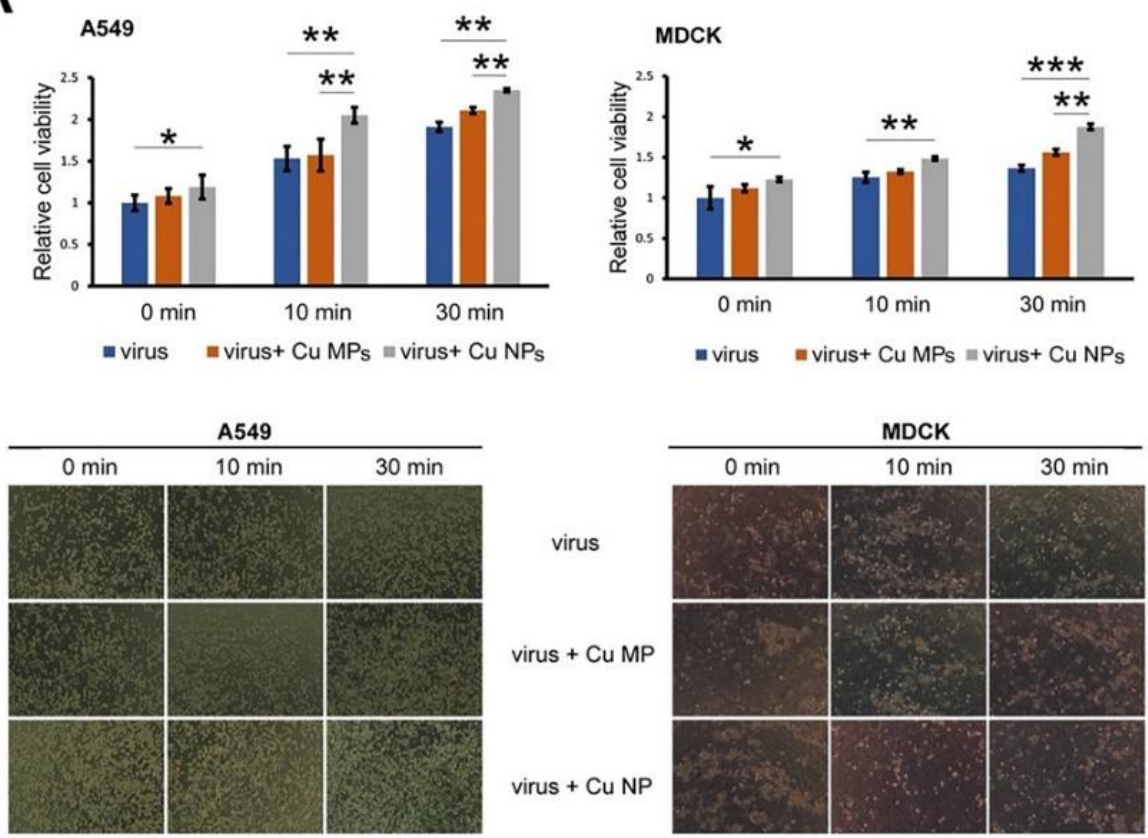

\section{B}

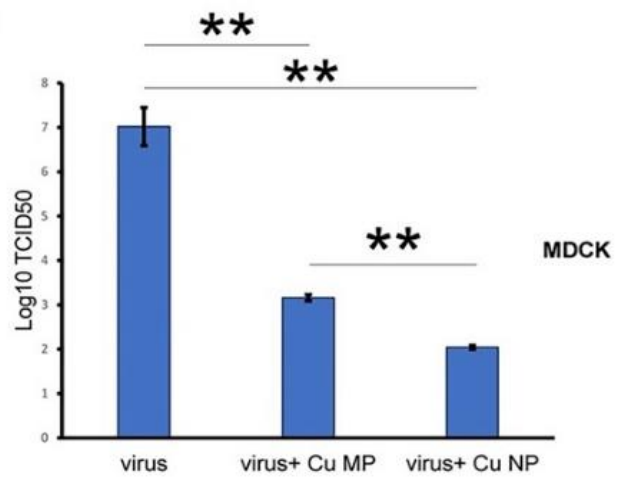

C
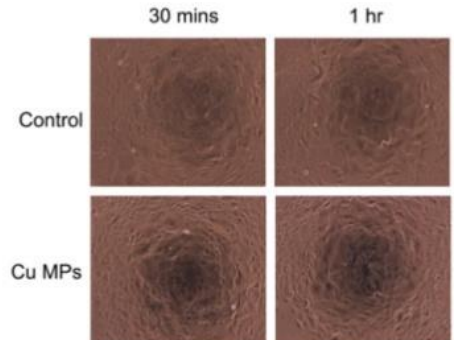

$2 \mathrm{hrs}$
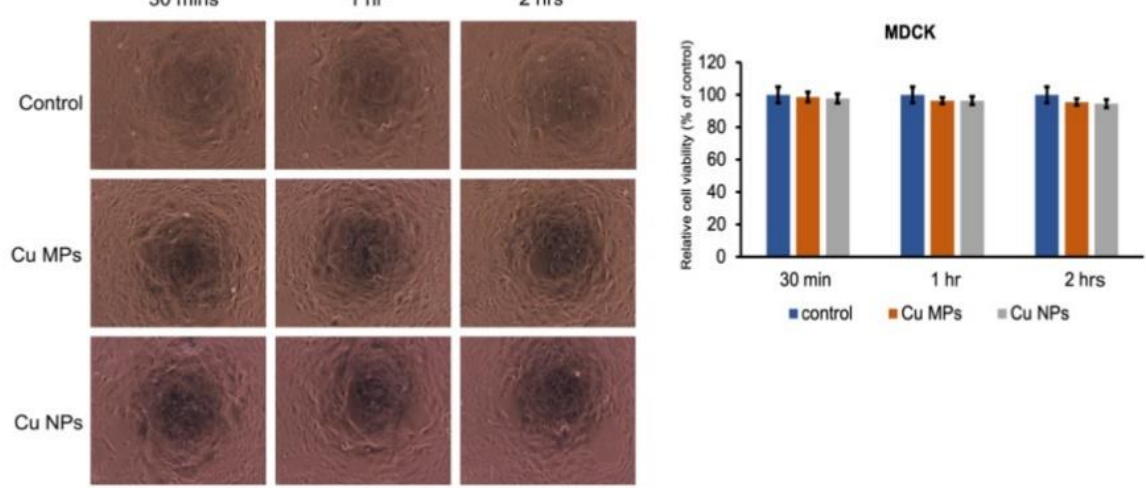

- control $=$ CuMPs $=$ CuNPs

Figure 7. Copper $(\mathrm{Cu})$ microparticles ( $\mathrm{Cu}$ MPs) and $\mathrm{Cu}$ nanoparticles ( $\mathrm{Cu}$ NPs) attenuate the cytopathic effect of H1N1 virus in A549 and MDCK cells. (A) Upper panels: cell viability assay for indicated cells. Lower panels: cell morphologies for indicated cells (magnification: $100 \times$ ). (B) TCID 50 assay for MDCK cells. (C) Cytotoxicity of Cu MPs and Cu NPs. ${ }^{* *}, p<0.001,{ }^{* *}, p<0.01, *, p<0.05$. 


\section{Conclusions}

In the current study, we showed that $80 \mathrm{kGy}$, not over $300 \mathrm{kGy}$, is required to produce a high-yield and reproducible synthesis of $\mathrm{Cu}$ NPs when the high energy E-beam $(10 \mathrm{MeV})$ is used. We also evaluated the antiviral activities of $\mathrm{Cu}$ NPs as compared to those of commercially available Cu MPs and demonstrated that Cu NPs show significantly higher, more efficient, and efficacious antiviral activities than $\mathrm{Cu}$ MPs, possibly due to a greater surface to volume ratio. The $\mathrm{Cu}$ NPs showed no visually present viral particles 30 minutes after contact with H1N1 virus, as evidenced by virus inactivation assay, western blot analysis, and confocal analysis. With the pandemic outbreak of COVID-19 in the year of 2020, we cannot exclude the possibility of another viral pandemic outbreak. Thus, the utilization of $\mathrm{Cu}$ NPs in the healthcare setting as well as in our everyday lives would greatly attenuate the risk of viral transmission, thereby contributing to the prevention of a potential pandemic outbreak of another virus in the future.

Author Contributions: Conceptualization, T.H., K.-M.K., and E.H.; methodology, T.H. and T.T.M.P.; validation, M.K.; formal analysis, T.H. and T.T.M.P.; investigation, T.H. and T.T.M.P.; resources, Y.-H.K. and J.-H.P.; data curation, J.H.S. writing-original draft preparation, T.H. and T.T.M.P.; writingreview and editing, K.-M.K. and E.H.; supervision, K.-M.K. and E.H.; funding acquisition, E.H. All authors have read and agreed to the published version of the manuscript.

Funding: This work was funded by the Basic Science Research Program through the National Research Foundation of Korea (NRF) funded by the Ministry of Education (2018R1A2B6006175).

Data Availability Statement: The data presented in this study are available on request from the corresponding author.

Conflicts of Interest: The authors declare no conflict of interest.

\section{References}

1. Li, J.; Lai, S.; Gao, G.F.; Shi, W. The emergence, genomic diversity and global spread of SARS-CoV-2. Nature 2021, 600, 408-418. [CrossRef] [PubMed]

2. Forman, R.; Azzopardi-Muscat, N.; Kirkby, V.; Lessof, S.; Nathan, N.L.; Pastorino, G.; Permanand, G.; van Schalkwyk, M.C.; Torbica, A.; Busse, R.; et al. Drawing light from the pandemic: Rethinking strategies for health policy and beyond. Health Policy 2021, 126, 1-6. [CrossRef] [PubMed]

3. Sreepadmanabh, M.; Sahu, A.K.; Chande, A. COVID-19: Advances in diagnostic tools, treatment strategies, and vaccine development. J. Biosci. 2020, 45, 1-20. [CrossRef]

4. Govind, V.; Bharadwaj, S.; Sai Ganesh, M.R.; Vishnu, J.; Shankar, K.V.; Shankar, B.; Rajesh, R. Antiviral properties of copper and its alloys to inactivate COVID-19 virus: A review. Biometals 2021, 34, 1217-1235. [CrossRef] [PubMed]

5. Olivares, M.; Uauy, R. Copper as an essential nutrient. Am. J. Clin. Nutr. 1996, 63, 791s-796s. [CrossRef]

6. Barceloux, D.G. Copper. J. Toxicol. Clin. Toxicol. 1999, 37, 217-230. [CrossRef] [PubMed]

7. Vincent, M.; Duval, R.E.; Hartemann, P.; Engels-Deutsch, M. Contact killing and antimicrobial properties of copper. J. Appl. Microbiol. 2018, 124, 1032-1046. [CrossRef]

8. Dollwet, H.H. Historic uses of copper compounds in medicine. Trace Elem. Med. 1985, 2, 80-87.

9. Bouraguba, M.; Glattard, E.; Naudé, M.; Pelletier, R.; Aisenbrey, C.; Bechinger, B.; Raibaut, L.; Lebrun, V.; Faller, P. Copperbinding motifs $\mathrm{Xxx}$-His or $\mathrm{Xxx}-\mathrm{Zzz}-\mathrm{His}$ (ATCUN) linked to an antimicrobial peptide: Cu-binding, antimicrobial activity and ROS production. J. Inorg. Biochem. 2020, 213, 111255. [CrossRef]

10. Addae, E.; Dong, X.; McCoy, E.; Yang, C.; Chen, W.; Yang, L. Investigation of antimicrobial activity of photothermal therapeutic gold/copper sulfide core/shell nanoparticles to bacterial spores and cells. J. Biol. Eng. 2014, 8, 11. [CrossRef]

11. Bezza, F.A.; Tichapondwa, S.M.; Chirwa, E.M.N. Fabrication of monodispersed copper oxide nanoparticles with potential application as antimicrobial agents. Sci. Rep. 2020, 10, 16680. [CrossRef]

12. Grass, G.; Rensing, C.; Solioz, M. Metallic copper as an antimicrobial surface. Appl. Environ. Microbiol. 2011, 77, 1541-1547. [CrossRef]

13. Gross, T.M.; Lahiri, J.; Golas, A.; Luo, J.; Verrier, F.; Kurzejewski, J.L.; Baker, D.E.; Wang, J.; Novak, P.F.; Snyder, M.J. Coppercontaining glass ceramic with high antimicrobial efficacy. Nat. Commun. 2019, 10, 1979. [CrossRef]

14. Zerbib, S.; Vallet, L.; Muggeo, A.; de Champs, C.; Lefebvre, A.; Jolly, D.; Kanagaratnam, L. Copper for the Prevention of Outbreaks of Health Care-Associated Infections in a Long-term Care Facility for Older Adults. J. Am. Med. Dir. Assoc. 2020, 21, 68-71.e1. [CrossRef] [PubMed]

15. Das, B.; Patra, S.; Jampílek, J.; Králová, K.; Bakirhan, N.; Uslu, B.; Ozkan, S.; Alfredo, N.; Rodríguez-Hernández, J.; Bernstein, A. Nanostructures for Antimicrobial Therapy: Nanostructures in Therapeutic Medicine Series; Elsevier: Amsterdam, The Netherland, 2017. 
16. Avilala, J.; Golla, N. Antibacterial and antiviral properties of silver nanoparticles synthesized by marine actinomycetes. Int. J. Pharm. Sci. Res. 2019, 10, 1223-1228.

17. Sreekanth, T.V.M.; Nagajyothi, P.C.; Muthuraman, P.; Enkhtaivan, G.; Vattikuti, S.V.P.; Tettey, C.O.; Kim, D.H.; Shim, J.; Yoo, K. Ultra-sonication-assisted silver nanoparticles using Panax ginseng root extract and their anti-cancer and antiviral activities. J. Photochem. Photobiol. B 2018, 188, 6-11. [CrossRef] [PubMed]

18. Galdiero, S.; Falanga, A.; Vitiello, M.; Cantisani, M.; Marra, V.; Galdiero, M. Silver nanoparticles as potential antiviral agents. Molecules 2011, 16, 8894-8918. [CrossRef] [PubMed]

19. Orłowski, P.; Kowalczyk, A.; Tomaszewska, E.; Ranoszek-Soliwoda, K.; Węgrzyn, A.; Grzesiak, J.; Celichowski, G.; Grobelny, J.; Eriksson, K.; Krzyzowska, M. Antiviral Activity of Tannic Acid Modified Silver Nanoparticles: Potential to Activate Immune Response in Herpes Genitalis. Viruses 2018, 10, 524. [CrossRef]

20. Gaikwad, S.; Ingle, A.; Gade, A.; Rai, M.; Falanga, A.; Incoronato, N.; Russo, L.; Galdiero, S.; Galdiero, M. Antiviral activity of mycosynthesized silver nanoparticles against herpes simplex virus and human parainfluenza virus type 3. Int. J. Nanomed. 2013, 8, 4303-4314.

21. Elechiguerra, J.L.; Burt, J.L.; Morones, J.R.; Camacho-Bragado, A.; Gao, X.; Lara, H.H.; Yacaman, M.J. Interaction of silver nanoparticles with HIV-1. J. Nanobiotechnol. 2005, 3, 6. [CrossRef]

22. Gherasim, O.; Puiu, R.A.; Bîrcă, A.C.; Burdușel, A.C.; Grumezescu, A.M. An Updated Review on Silver Nanoparticles in Biomedicine. Nanomaterials 2020, 10, 2318. [CrossRef]

23. Yang, X.X.; Li, C.M.; Huang, C.Z. Curcumin modified silver nanoparticles for highly efficient inhibition of respiratory syncytial virus infection. Nanoscale 2016, 8, 3040-3048. [CrossRef]

24. Lin, Z.; Li, Y.; Guo, M.; Xu, T.; Wang, C.; Zhao, M.; Wang, H.; Chen, T.; Zhu, B. The inhibition of H1N1 influenza virus-induced apoptosis by silver nanoparticles functionalized with zanamivir. RSC Adv. 2017, 7, 742-750. [CrossRef]

25. Park, J.H.; Kim, C.W.; Lee, B.C. Oxidation Stability of Conductive Copper Paste Prepared through Electron Beam Irradiation. Appl. Sci. Converg. Tec. 2020, 29, 103-107. [CrossRef]

26. Reed, L.J.; Muench, H. A Simple Method of Estimating Fifty per cent Endpoints12. Am. J. Epidemiol. 1938, 27, 493-497. [CrossRef]

27. Zhou, F.; Zhou, R.; Hao, X.; Wu, X.; Rao, W.; Chen, Y.; Gao, D. Influences of surfactant (PVA) concentration and pH on the preparation of copper nanoparticles by electron beam irradiation. Radiat. Phys. Chem. 2008, 77, 169-173. [CrossRef]

28. Ali, Z.; Ghazy, O.; Meligi, G.; Saleh, H.; Bekhit, M. Radiation-induced synthesis of Copper/Poly (vinyl alcohol) nanocomposites and their catalytic activity. Adv. Polym. Technol. 2018, 37, 365-375. [CrossRef]

29. Joshi, S.; Patil, S.; Iyer, V.; Mahumuni, S. Radiation induced synthesis and characterization of copper nanoparticles. Nanost. Mater. 1998, 10, 1135-1144. [CrossRef]

30. Liu, Z.; Bando, Y. A novel method for preparing copper nanorods and nanowires. Adv. Mater. 2003, 15, 303-305. [CrossRef]

31. Lisiecki, I.; Billoudet, F.; Pileni, M. Control of the shape and the size of copper metallic particles. J. Phys. Chem. 1996, 100, 4160-4166. [CrossRef]

32. Yagi, S.; Nakanishi, H.; Matsubara, E.; Matsubara, S.; Ichitsubo, T.; Hosoya, K.; Matsuba, Y. Formation of Cu nanoparticles by electroless deposition using aqueous CuO suspension. J. Electrochem. Soc. 2008, 155, D474. [CrossRef]

33. Sreeju, N.; Rufus, A.; Philip, D. Microwave-assisted rapid synthesis of copper nanoparticles with exceptional stability and their multifaceted applications. J. Mol. Liq. 2016, 221, 1008-1021. [CrossRef]

34. Rodrigues, I.; Guedes, M.; Ferro, A.C. Microstructural changes in copper-graphite-alumina nanocomposites produced by mechanical alloying. Microsc. Microanal. 2015, 21, 120-131. [CrossRef]

35. Laroui, H.; Wilson, D.S.; Dalmasso, G.; Salaita, K.; Murthy, N.; Sitaraman, S.V.; Merlin, D. Nanomedicine in GI. Am. J. Physiol. Gastrointest. Liver Physiol. 2011, 300, G371-G383. [CrossRef]

36. Schaper, A.; Hou, H.; Greiner, A.; Schneider, R.; Phillipp, F. Copper nanoparticles encapsulated in multi-shell carbon cages. Appl. Phys. A 2004, 78, 73-77. [CrossRef]

37. Pergolese, B.; Muniz-Miranda, M.; Bigotto, A. Surface-enhanced Raman scattering investigation of the adsorption of 2mercaptobenzoxazole on smooth copper surfaces doped with silver colloidal nanoparticles. J. Phys. Chem. B 2006, 110, 9241-9245. [CrossRef]

38. Hang, X.; Peng, H.; Song, H.; Qi, Z.; Miao, X.; Xu, W. Antiviral activity of cuprous oxide nanoparticles against Hepatitis C Virus in vitro. J. Virol. Methods 2015, 222, 150-157. [CrossRef]

39. Tavakoli, A.; Hashemzadeh, M.S. Inhibition of herpes simplex virus type 1 by copper oxide nanoparticles. J. Virol. Methods 2020, 275, 113688. [CrossRef]

40. Minoshima, M.; Lu, Y.; Kimura, T.; Nakano, R.; Ishiguro, H.; Kubota, Y.; Hashimoto, K.; Sunada, K. Comparison of the antiviral effect of solid-state copper and silver compounds. J. Hazard. Mater. 2016, 312, 1-7. [CrossRef]

41. Seok, J.H.; Kim, H.; Lee, D.B.; An, J.S.; Kim, E.J.; Lee, J.-H.; Chung, M.S.; Kim, K.H. Divalent cation-induced conformational changes of influenza virus hemagglutinin. Sci. Rep. 2020, 10, 1-11. [CrossRef]

42. Gordon, N.A.; McGuire, K.L.; Wallentine, S.K.; Mohl, G.A.; Lynch, J.D.; Harrison, R.G.; Busath, D.D. Divalent copper complexes as influenza A M2 inhibitors. Antivir. Res. 2017, 147, 100-106. [CrossRef]

43. Gandhi, C.S.; Shuck, K.; Lear, J.D.; Dieckmann, G.R.; DeGrado, W.F.; Lamb, R.A.; Pinto, L.H. Cu(II) inhibition of the proton translocation machinery of the influenza A virus M2 protein. J. Biol. Chem. 1999, 274, 5474-5482. [CrossRef] [PubMed] 
44. Raha, S.; Mallick, R.; Basak, S.; Duttaroy, A.K. Is copper beneficial for COVID-19 patients? Med. Hypotheses 2020, $142,109814$. [CrossRef]

45. Dou, D.; Revol, R.; Östbye, H.; Wang, H.; Daniels, R. Influenza A Virus Cell Entry, Replication, Virion Assembly and Movement. Front. Immunol. 2018, 9, 1581. [CrossRef] [PubMed]

46. Hu, Y.; Sneyd, H.; Dekant, R.; Wang, J. Influenza A Virus Nucleoprotein: A Highly Conserved Multi-Functional Viral Protein as a Hot Antiviral Drug Target. Curr. Top. Med. Chem. 2017, 17, 2271-2285. [CrossRef] [PubMed]

47. Stanley, W.M. The size of influenza virus. J. Exp. Med. 1944, 79, 267-283. [CrossRef]

48. Amodeo, A.A.; Skotheim, J.M. Cell-Size Control. Cold Spring Harb. Perspect. Biol. 2016, 8, a019083. [CrossRef] [PubMed] 